\title{
ИСТОРИКО-ПРАВОВОЙ РАКУРС К ПРОБЛЕМЕ МИРНОГО ДОГОВОРА СССР (РОССИИ) С ЯПОНИЕЙ
}

\begin{abstract}
Аннотация: 31 января 2014 года в Токио состоялся очередной раунд регулярных консультаций на уровне заместителей министров иностранных дел России и Японии (с российской стороны - И.В.Моргулов, с японской - С.Сугияма). В ходе консультаций основное внимание было уделено вопросам дальнейшего продвижения российско-японского сотрудничества, включая углубление политического диалога, расширение торгово-экономических связей, развитие контактов в практических областях и культурных обменов в свете реализации договоренностей, достигнутых на встречах руководителей двух стран в 2013 году. Был также проведен обмен мнениями по ряду актуальных международных тем, в том числе вопросам обеспечения безопасности и снижения конфликтного потенциала в Азиатско-Тихоокеанском регионе. В соответствии с поручением лидеров двух стран - России и Японии - состоялось обсуждение проблемы заключения мирного договора между Россией и Японией, в частности ее исторических аспектов. Стороны договорились о проведении следующего раунда консультаций в Москве. Конкретные сроки будут согласованы по дипломатическим каналам.
\end{abstract}

Ключевые слова: международные отношения, внешняя политика, Россия, Япония, политическая стабильность, мирный договор, конфлликт, интересы, ценности, спорные территории.

31 января 2014 года в Токио состоялся очередной раунд регулярных консультаций на уровне заместителей министров иностранных дел России и Японии (с российской стороны - И.В.Моргулов, с японской - С.Сугияма).

В ходе консультаций основное внимание было уделено вопросам дальнейшего продвижения российско-японского сотрудничества, включая углубление политического диалога, расширение торгово-экономических связей, развитие контактов в практических областях и культурных обменов в свете реализации договоренностей, достигнутых на встречах руководителей двух стран в 2013 году.

Был также проведен обмен мнениями по ряду актуальных международных тем, в том числе вопросам обеспечения безопасности и снижения конфликтного потенциала в Азиатско-Тихоокеанском регионе.

В соответствии с поручением лидеров двух стран состоялось обсуждение проблемы заключения мирного договора между Россией и Японией, в частности ее исторических аспектов.

Стороны договорились о проведении следующего раунда консультаций в Москве. Конкретные сроки будут согласованы по дипломатическим каналам.

Напомним, что такая встреча стала возможной благодаря договоренности в апреле 2013 года между Президентом Российской Федерации В.В. Путиным и премьер-министром Японии
Синдзо Абэ во время официального визита последнего в Москву ${ }^{1}$.

В современном глобальном мире самое главное в решении геополитических проблем, в том числе и для России и для Японии, заключается в расширении и взаимозависимости в сфере экономики, культуры, образования, научного обмена и туризма. Конечно, и для Японии, как нам представляется, не снимается с повести дня и территориальный вопрос посредством достижения компромиссного варианта. Из трех острых территориальных споров и притязаний, которые Япония имеет на сегодняшний день, - с Китаем, Южной Кореей и Россией, она хотела бы договориться прежде всего именно с нами.

Кстати, представители Советский Союза, и в последующем Россия, неоднократно высказывались о своей готовности к широкому сотрудничеству с Японией. Боле того, для создания простой основы такого сотрудничества предполагалось заключить мирный договор между обеими странами. Препятствием тому стали главным образом, на наш взгляд, необоснованные японские территориальные притязания. ${ }^{2}$

\footnotetext{
Российская газета. 2013. 27 декабря.

2 Анисимов Л.Н. Международное право о несостоятельности территориальных притязаний Японии к России как продолжателю СССР//Дипломатическая служба. 2014. №1. C. $36-44$
} 
Нелишне заметить, что значение территории как материальной основы государства не нуждается в особых пояснениях. Не случайно на протяжении всей истории велись непрерывные войны за захват новых земель. Защита территории - одна из главных составляющих задач государства. Так, согласно Конституции РФ «Российская Федерация обеспечивает целостность и неприкосновенность своей территории» (ч. 3 ст. 4). Должное внимание проблемам государственной территории уделено и в международном праве, где, в частности, закреплены такие основополагающие принципы, как неприменение силы, территориальная целостность, нерушимость границ. ${ }^{3}$ Иными словами, всякое государство должно воздерживаться от угрозы силой или ее применения в отношении любого государства.

Каков бы ни был результат российско-японских консультаций для неспециалистов он может быть необъясним хотя бы без краткого анализа международно-правовых документов, касающихся итогов Второй мировой войны и непоследовательной, гегемонистской, неправовой позиции США в отношении заключения мирного договора с Японией. Как известно, первый раунд российскояпонских консультаций относительно мирного договора состоялся в Москве в августе 2013 года. По договоренности сторон результаты консультаций не разглашались...

С подписанием 2 сентября 1945 года Акта о капитуляции Японии ${ }^{4}$, закрылась одна из последних страниц Второй мировой войны. Правда, к моменту нападения Гитлера на Польшу на основании «мюнхенского сговора», а затем вероломного вторжения на территорию СССР, уже с 1935 года полным ходом шла война в Азии с японскими захватчиками. И в этой войне уже к 1939 году по-

\footnotetext{
3 Подробно об этом, например, см.: Клименко Б.М. Государственная территория. Вопросы теории и практики международного права. - М., 1974. С. 38 - 86; Клименко Б.М., Ушаков Н.А. Нерушимость границ - условия международного мира. - М., 1975. С .20 - 22, 32 - 45, 120 - 135.

4 Фактически это была безоговорочная капитуляция, так как требование о ее немедленном осуществлении выдвинуто Союзными Державами в Потсдамской декларации, составленной на основе ранее принятых международных соглашений, таких как Каирская декларация и в которой включен, помимо требования безоговорочной капитуляции всех японских вооруженных сил, полный перечень статей относительно политического, экономического и социального устройства Японии (подробно об этом, например, см.: Зимонин В.П. Последняя точка во Второй мировой войне. - М., 2005. C. 16-55).
}

тери только Китая составили 20 млн человеческих жизней ${ }^{5}$. Отсюда следует, что война в Азии стала составной трагической частью Второй мировой войны и была завершена вместе с капитуляцией японских милитаристов.

И не тогда ли началась Вторая мировая война, когда Япония напала на Китай?!

Между тем, комментируя дискуссию о начале Второй мировой войны, директор Института истории, естествознания и техники имени С.И. Вавилова РАН, член-корреспондент РАН Ю.Н. Батурин в одном из своих интервью отметил следующее: «Суть в том, что событие - начало Второй мировой войны» - «долгая длительность» ${ }^{6}$. То есть исподволь создавались предпосылки к войне, велись и проваливались дипломатические переговоры, каждая страна пыталась защитить себя и свои интересы разными способами. И лишь когда геополитическая «мозаика» уложилась в целостную картину, оказалось, что война уже идет» ${ }^{7}$.

Среди победителей, присутствовавших при подписании капитуляции Японии на борту американского флагманского линкора «Миссури», находившегося в Токийском заливе, находились также представители европейских государств: Франции и Нидерландов, присутствовали также военные Китая, Канады, Австралии, Новой Зеландии ${ }^{8}$. Акт о безоговорочной капитуляции Японии от имени императора, японского правительства и императорской ставки подписали министр иностранных дел М. Сигэмицу и начальник генерального штаба японской армии Ё. Умэдзу. От имени всех союзных держав, находившихся в состоянии войны с Японией, Акт подписал американский генерал Д.Макартур; от имени отдельных стран - адмирал Ч. Нимиц (США), генерал Су Юнчан (Китай), адмирал Б. Фрейзер (Великобритания), генерал-лейтенант К.Н.Деревянко (СССР), генерал Т. Блэйман (Австралия), полковник Н. Мур-Косгрейв (Канада),

\footnotetext{
5 В целом потери Китая во время Второй мировой войны составили 35 млн человек (см.: Российская газета. 2010. 31 августа).

6 Понятие «долгая длительность» предложил использовать французский историк Фернан Бродель для анализа и описания истории.

Российская газета. 2013. 19 ноября.

8 В последующем, спустя десятилетия, этот исторический линкор навечно стал на якорь у Гавайских островов, фактически вписавшись в мемориал жертвам Пёрл-Харбора - военной базы США, которая подверглась сокрушительному японскому нападению 7 декабря 1941 года.
} 
генерал Ф. Леклер (Франция), адмирал К. Хелфриг (Нидералнды) и вице-маршал авиации Л. Исит (Новая Зеландия) 9 . В Акте о капитуляции японская сторона четко заявила, что «настоящим принимает условия Декларации, опубликованной 26 июля в Потсдаме главами правительств США, Китая и Великобритании, к которым впоследствии присоединился и СССР» ${ }^{10}$.

Наиболее ощутимым результатом поражения Японии прежде всего явился распад ее колониальной империи и отход от нее территорий, «которые она захватила при помощи силы и в результате своей алчности» ${ }^{11}$.

Как же развивались события до краха японского милитаризма и до того как встал вопрос о мирном договоре с сокрушенной Японией?

Когда уже в Европе во всю полыхала война и гитлеровская армия вероломно вторглась на территорию СССР, 11 декабря 1941 года Германия, Италия и Япония подписали трехсторонний пакт, по которому последняя стала политическим союзником гитлеровской Германии. Видимо, японская сторона запамятовала, что еще 13 апреля 1941 года в Кремле был подписан Пакт о нейтралитете между СССР и Японией. Вступив в указанный военный альянс, Япония тем самым дезавуировала взятые на себя обязательства по отношению к СССР и оказывала реальную поддержку фашистской Германии. Такое поведение, естественно, с позиции международного права освобождает другую сторону от выполнения указанного Пакта.

Учитывая, что Япония нарушила условия советско-японского Пакта о нейтралитете, Советское правительство 5 мая 1945 года денонсировало этот договор ${ }^{12}$. К тому же Япония активно готовилась и выжидала удобный момент для нападения на СССР. На границе с Советским Союзом сосредоточивались огромные людские ресурсы и военно-технические средства. К 1 января 1942 года численность японской Квантунской армии у наших границ достигла 1,1 млн человек (17 пехотных дивизий и 5 отдельных бригад) ${ }^{13}$.

\footnotetext{
9 См.: Зимянин В.П. Указ. соч. С.52 - 53.

10 Сборник действующих договоров... Указ соч. С.137.

11 Каирская декларация: сборник действующих договоров... Указ соч. С.105 - 106.

12 См.: Николаев А.Н. Токио: суд народов. - М.,1990. С.18.

13 Во всей Японской сухопутной армии тогда насчитывалось 2,1 млн человек в составе 56 дивизий и 25 отдельных бригад и, следовательно, у наших границ была сосредоточе-
}

Концентрация столь крупных вооруженных сил, непрерывное усиление их технической оснащенности, а также провокационные нарушения советской границы, закрытие проливов для советских судов, соединявших Владивосток с восточными регионами нашей страны и с Соединенными Штатами, неоднократные случаи задержания, обстрела и даже потопления наших судов, все это, помимо прочего, создавало исключительную напряженность на дальневосточных рубежах Советского Союза. Между тем аппетиты японских милитаристов росли. Так, в плане, одобренном военным министерством и министерством колоний Японии, предусматривалось присоединение к владениям Японской империи Приморского края, районов, прилегающих к Манчжоу-го, а также других советских территорий до озера Байкал. «Вопрос о районах Сибири и будущем всей советской дальневосточной территории, - отмечает Д.И. Гольденберг, - предлагалось разрешить на базе японо-германского соглашения» ${ }^{14}$.

Угроза вот-вот могла превратиться в реальность. Интересы обороны СССР требовали в короткие сроки пойти навстречу просьбам союзников принять участие в сокрушении японских милитаристов. В этой связи Советское правительство информировало правительство США, что оно с пониманием относится к проблемам союзников и, как только появятся реальные возможности, берет на себя конкретное обязательство: присоединиться к Америке и Англии в борьбе с японской агрессией. (О позиции Советского правительства было сообщено президенту США Ф.Рузвельту во время пребывания в Москве его официального посланника Хэрли) ${ }^{15}$. На Московском совещании министров иностранных дел СССР и США в октябре 1943 года вопрос об участии Советского Союза в войне против Японии рассматривался уже как отвечающий интересам всех союзников. И. Сталин определенно сообщил госсекретарю США Хэллу, что СССР вступает в войну с Японией сразу же после разгрома гитлеровской Германии. Такая политика и дипломатия СССР вынуждала США и их союзников в последующем при принятии ими международно-

на половина японских сухопутных армий (см.: Гольденберг Д.И. Внешняя политика Японии в 1941 - 1945 гг. - М., 1962. С.74-75).

14 Гольденбере Д.И. Указ. соч. С.70.

15 Кузнец Ю.Л. От Пёрл-Харбора до Потсдама. - М., 1970. C.135. 
правовых документов учитывать политические интересы СССР, в том числе касающихся отторгнутых от него в свое время японским агрессором территорий.

В начале феврале 1945 года на Конференции в Ялте (Крымская конференция, 4-11 февраля) с участием глав правительств СССР, США и Англии американская делегация предложила обсудить вопрос об условиях вступления СССР в войну против Японии, где союзники были вынуждены признать исконные исторические права СССР на Сахалин и Курильские острова. 11 февраля 1945 года главы указанных правительств подписали Ялтинское соглашение, которое в развитие Каирской декларации 1941 года конкретизировало условия участия СССР в войне против Японии. Этим соглашением предусматривалось, что Советский Союз вступит в войну против Японии на стороне союзников при условии восстановления «принадлежащих России прав, нарушенных вероломным нападением Японии в 1904 году, а именно: возвращение Советскому Союзе южной части острова Сахалин и всех прилегающих к ней островов. Передачу Советскому Союзу Курильских островов» ${ }^{16}$. Главы делегаций приняли это как бесспорное и обязательное условие после победы над Японией. В частности, премьер-министр Великобритании У. Черчилль, выступая от имени англо-американской стороны, заявил, что удовлетворен тем, как решены дальневосточные вопросы. «Мы будем рады видеть русские корабли на Тихом океане, и одобряем восполнение потерь, понесенных Россией в русскояпонской войне» ${ }^{17}$ - заверил У. Черчилль. Таким образом, мы имеем полное основание указанные выше условия Ялтинского соглашения рассматривать как юридически закрепляющие в международно-правовом плане, как один из окончательных итогов Второй мировой войны на основе правовой договоренности и воли стран, ведущих эту войну. Более конкретные вопросы, касающиеся условий капитуляции, объема границ и суверенитета, цели оккупации и другое изложены в Потсдамской декларации глав правительств США, Соединенного Королевства и Китая от 26 июля 1945 года, к которой Советский Союз официально присоединил-

\footnotetext{
16 Внешняя политика Советского Союза в период Отечественной войны. - М., 1947. С.110-112; Ялтинское соглашение трех великих держав по вопросам Дальнего Востока// Внешняя политика в период Отечественной войны. Т.3. - М., 1947. C.111-112.

17 W.Churchill. The Second War. Vol. VI. P. 389.
}

ся 8 августа 1945 года ${ }^{18}$. В этот же день Советское правительство сделало Заявление правительству Японии, в котором, в частности, указывалось: «учитывая отказ Японии капитулировать, в ответ на предложение союзников, оно приняло решение включиться в войну против японской агрессии» и тем самым «сократить сроки окончания войны, сократить количество жертв и содействовать скорейшему восстановлению мира» ${ }^{19}$.

Война СССР с милитаристской Японией началась 9 августа 1945 года и, после сокрушительного удара советских войск, 14 августа 1945 года правительство этой страны согласилось с условиями капитуляции, изложенными в Потсдамской декларации союзных держав, принятой на Потсдамской конференции 26 июля 1945 года. Заметим: в Потсдамской декларации в качестве основной задачи для установления мира, безопасности и справедливости выдвигались безусловные требования о том, что «навсегда должны быть устранены власть и влияние тех, которые обманули и ввели в заблуждение народ Японии, заставив его идти по пути всемирных завоеваний» ${ }^{20}$, то есть должен быть навсегда и бесповоротно уничтожен безответственный милитаризм. В то же время союзными державами заявлено, что в соответствии с условиями Каирской декларации, суверенитет Японии ограничивается «островами Хонсю, Хоккайдо, Кюсю, Сикоку и теми менее крупными островами, которые мы укажем» ${ }^{21}$.

На Потсдамской конференции, наряду с другими важными вопросами, утвержден Совет Министров Иностранных Дел (СМИД) в качестве международного политико-правового органа пяти великих держав (СССР, Китая, США, Англии и Франции) для проведения необходимой подготовитель-

\footnotetext{
1828 июля 1945 года японское правительство отклонило условия Потсдамской декларации (см.: Николаев А.Н. Указ. соч. С.18).

19 Сборник действующих договоров... Указ. соч. С.105-106. Война принесла японскому народу много горя и страданий: убиты 2,5 млн и искалечено 94,5 тысяч японских военнослужащих. Потери гражданского населения составили 668 тысяч человек, включая около 300 тысяч убитыми. 640 тысяч были взяты в плен. В результате атомной бомбардировки уничтожены Херосима и Нагасаки и погибли сотни тысяч людей (см.: Николаев А.Н. Указ. соч. С.8).

20 Потсдамская декларация// Сборник действующих договоров, соглашений и конвенций, заключенных СССР с иностранными государствами. Вып. XI. - М., 1955. С.104-106.

21 Потсдамская декларация// Сборник действующих договоров, соглашений и конвенций, заключенных СССР с иностранными государствами. Вып. ХI. - M, 1955. С.104-106.
} 


\section{Международные отношения / International Relations}

ной работы по мирному урегулированию и для обсуждения других вопросов, которые по согласованию сторон могли время от времени передаваться Совету. Решения СМИД принимались на основе единогласия всех участвующих в его работе членов Совета Министров Иностранных Дел и имели силу международно-правовых документов.

Главным принципом работы СМИД в области мирного урегулирования после Второй мировой войны явились решения Ялтинской и Потсдамской конференций руководителей великих держав. В данном случае Совет способствовал делу мира и безопасности, и его работа оказалась плодотворной. Благодаря принципиальной позиции Советского Союза СМИД в основном успешно выполнил возложенную на него задачу по составлению окончательных текстов мирных договоров с Италией, Финляндией, Венгрией, Болгарией и Румынией.

Оставляя за скобками другие вопросы, касающиеся международных отношений с Японией, мы продолжим (в рамках данной статьи) исследование документов и событий, связанных с дипломатической борьбой относительно подписания мирного договора с побежденным и агрессивным государством.

В декабре 1945 года в Москве на конференции министров иностранных дел СССР, США, Англии и Китая, благодаря усилиям советской дипломатии, достигнуто компромиссное решение о принципах осуществления условий, касающиеся капитуляции Японии, зафиксированных Потсдамской декларацией. Было принято решение о создании двух органов - Дальневосточной комиссии, с местопребыванием в Вашингтоне в составе представителей стран, участвовавших в войне против Японии ${ }^{22}$, и Союзного Совета для Японии из представителей СССР, США, Великобритании и Китая, с местопребыванием в Токио. Дальневосточная комиссия являлась совещательным органом.

Функции Дальневосточной комиссии заключались в том, чтобы «формировать политическую линию, принципы и общие основания, в соответствии с которыми может осуществляться выполнение Японией ее обязательств по условиям капитуляции» ${ }^{23}$. При этом Комиссия не наделялась

22 В Дальневосточную комиссию входили СССР, США, Англия, Китай, Франция, Голландия, Канада, Австралия, Новая Зеландия, Индия и Филиппины. Позже в ДВК вошли Бирма и Пакистан.

23 Внешняя политика Советского Союза. 1945. - М., 1949. C. $155-160$. правом давать рекомендации в отношении урегулирования территориальных вопросов, поскольку они были решены рассмотренными выше международно-правовыми соглашениями между главами союзных держав и всякое обсуждение означало бы попытку их ревизии. В свою очередь Союзный Совет для Японии учрежден на предмет консультаций с Главнокомандующим и дачи ему советов по вопросам, касающимся осуществления условий капитуляции и контроля над Японией, а также выполнением ею возложенных на нее директив, дополняющих эти условия ${ }^{24}$. Положением о Совете предусматривалось, что Главнокомандующий является единственной исполнительной властью Союзных Держав в Японии. При этом отметим, что несмотря на создание Дальневосточной Комиссии и Союзного Совета для Японии и наделение их указанными функциями, важнейшие вопросы политики в отношении Японии могли решить лишь в рамках действительного легитимного органа - Совета Министров Иностранных Дел, предусмотренного Потсдамской конференции.

19 июля 1949 года Дальневосточная Комиссия приняла документ «Об основной политике в отношении Японии после капитуляции». В ней недвусмысленно указывалось: «обеспечить, чтобы Япония не представляла больше угрозы международному миру» и предусматривала проведение широких мероприятий демократического характера внутри страны вплоть до создания «демократического мирного правительства, которое будет выполнять свои международные обязательства, будет уважать права других государств и будет поддерживать цели Объединенных Наций» ${ }^{25}$.Этот документ, а также ряд решений Союзного Совета, побуждали Японию к демократическим преобразованиям и в известной мере являлись поступательным движением к заключению мирного договора с Японией.

Между тем американская сторона стала тормозить и сворачивать работу Дальневосточной Комиссии и Союзного Совета для Японии, добиваясь подчинения такого мирного договора, который бы юридически закрепил оккупацию Соединенными Штатами этой страны и обеспечил бы им в ней безраздельное господство. В этом плане американское правительство, стремясь обойти Совет Мини-

24 Внешняя политика Советского Союза. 1945. - М., 1949. C. $155-160$.

25 Сборник решений Дальневосточной Комиссии (февраль 1946 - июль 1948 гг).. - М., МИД СССР, 1948. C. 1215 . 
стров Иностранных Дел, где был установлен принцип единогласия, предложило созвать 19 августа 1947 года конференцию по составлению мирного договора из представителей 11 держав - участниц Дальневосточной Комиссии. При этом США выдвинули необоснованный довод против предварительного рассмотрения вопроса о созыве Конференции мирного договора с Японией Советом министров иностранных дел четырех держав - СССР, США, Великобритания и Китай, поскольку, дескать, это не входит в его функции.

В памятной записке Правительству США от 29 августа 1947 года Советское правительство отклонило американские доводы о неправомерности Сoвета Министров Иностранных Дел (СМИД), указав, что он создан Потсдамским решением по мирному урегулированию. Это решение отнюдь не предусматривает ограничения необходимой работы в отношении стран Европы. Сам состав Совета Министров Иностранных Дел говорит об обратном. Включение в его состав представителя Китая свидетельствует о том, что вопросы мирного урегулирования в отношении Японии также относятся к компетенции Совета Министров Иностранных Дел ${ }^{26}$. А ларчик, как говорится, открывался просто. Теряя почву в Китае в результате успешных операций Народно-освободительной армии, США пытались подготовить в случае необходимости условия, чтобы отстранить народное правительство Китая от решения японских дел. Со своей стороны Советское правительство продолжало настаивать и 27 ноября 1947 года предложило созвать Совет Министров Иностранных Дел в январе 1948 года для обсуждения вопроса о мирном договоре с Японией ${ }^{27}$. Однако советское предложение не было принято, как и последующие.

Становилось вполне очевидным, что США стремились создать на Дальнем Востоке обстановку особой напряженности и все усилия направили на создание себе союзника в лице Японии. Поэтому с конца 1947 года американская дипломатия не формировала вопрос о мирном договоре. В свою очередь Советское правительство в ходе дипломатической переписки неоднократно обращало

\footnotetext{
26 Сборник нот и заявлений правительств СССР, США, Китая, Англии и других стран по вопросам мирного урегулирования для Японии. Июль 1947- июль 1951 гг.. - М., МИД СССР 1951. С.8-10.

27 Сборник нот и заявлений правительств СССР, США, Китая, Англии и других стран по вопросам мирного урегулирования для Японии. Июль 1947- июль 1951гг. - М., МИД CCCP. 1951. C.8-10.
}

внимание правительств США и Англии о необходимости ускорения решения вопроса о мирном договоре с Японией.

Между тем, став на путь противостояния государств с различными социально-экономическими системами и отказа от сотрудничества с СССР, три члена СМИД - США, Англия и Франция срывали и саботировали его работу. Проводя политику фактической ликвидации СМИД, эти государства стремились решить относящиеся к его компетенции вопросы в других органах, где они имели обеспеченное большинство. В конце концов СМИД был отстранен от подготовки мирного договора с Японией, незаконно принятого в последующем под диктатом США в ином, выгодном им, варианте.

США стали самолично готовить так называемую мирную конференцию и проект мирного договора с Японией. Рассылать начали 29 марта 1951 года. При этом США утверждали, что он сформулирован после обмена мнениями с другими государствами, в том числе и с Советским Союзом, хотя наша сторона занимала совершенно иную позицию, соответствующую ранее принятым международным документам относительно послевоенного устройства Японии. Всего США разослали 54 приглашения на конференцию в Сан-Франциско, где 4 сентября предполагалось открытие мероприятия по подписанию мирного договора. Советское правительство заявило, что оно «направляет свою делегацию на конференцию в Сан-Франциско и представит предложение о мирном договоре с Японией». ${ }^{28}$

Ввиду того, что англо-американский договор не отвечал целям и задачам, которые преследовались Объединенными Нациями в отношении Японии, советская делегация внесла соответствующие поправки и дополнения. Их принятие позволило бы превратить Сан-Францисский мирный договор в документ, действительно служащий интересам мирного урегулирования на Дальнем Востоке. Поправки и дополнения касались следующих важных вопросов:

«1. Недопущение возрождения японского милитаризма.

2. Выводы с территории Японии иностранных оккупационных войск и недопущение создания на территории Японии иностранных военных баз.

3. Недопущение вступления Японии в коалищии или военные союзы, направленные против какихлибо держав, принимавшей участие в войне против Японии.

28 Сборник документов и материалов по Японии. 19511954. - M., 1954. 


\section{Международные отношения / International Relations}

4. Разрешение территориальных вопросов в точном соответствии с существующими международными соглашениями по данному вопросу.

5. Обеспечение японскому народу демократических прав и свобод.

6. Беспрепятственное развитие Японией мирной промышленности, развитие торговли с другими государствами и ее допуск к сырьевым ресурсам» ${ }^{29}$.

Тем не менее, Соединенные Штаты путем открытого нажима на участников конференции и использования методов механического голосования отвергли поправки советской стороны и 8 сентября 1951года был принят американо-английский проект Сан-Францисского мирного договора ${ }^{30}$. Разумеется, Советский Союз не мог присоединиться к подобному партнерству. Прежде всего это не отвечало его дипломатической линии на безусловное выполнение договорных обязательств военного времени в контексте юридического закрепления итогов Второй мировой войны и ликвидации основы для создания японского милитаризма и создания нового очага войны на Дальнем Востоке.

Кстати, в Сан-Францисском договоре преднамеренно искажены положения Каирской декларации, Ялтинского соглашения и Потсдамской декларации относительно территориальных вопросов. Договор содержит отказ Японии от права на Тайвань, Пескадорские, Парасельские и другие острова, но сознательно умалчивается о дальнейшей судьбе этих территорий и принадлежности их Китайской Народной Республике. Точно так же отказ Японии не зафиксирован от всех прав, правооснований и притязаний на Курильские острова и ту часть острова Сахалин и принадлежащих к нему островов, суверенитет над которыми Япония приобрела по Потсдамскому договору от 5 сентября 1905 года. Более того, не определена четко историческая принадлежность этих островов ${ }^{31}$, а также бесспорная обязанность Японии признать суверенитет Советского Союза на эти территории, как это предусматривалось вышеуказанными международными соглашениями. К тому же, оставлено не правовое поле для создания напряжения на Дальнем Востоке и неправомерная неурегулирован-

29 Заявление А.А. Громыко на пресс-конференции в СанФранциско 8 сентября 1951 года // Правда. 1951. 10 сентября.

30 Автор не ставил перед собой задачу дать постатейный анализ этого документа.

31 Подробно об этом, например, см.: «Русские Курилы: История и современность: Сборник документов по формированию русско-японской и советско-японской границы. - М., 1955. ность международных отношений СССР - Россия - Япония в необозримом будущем.

Тем временем в день подписания СанФранцисского мирного договора правительство США заставили японцев подписать «Договор безопасности между Соединенными Штатами и Японией». США получили право размещать наземные, воздушные и морские силы в Японии и вблизи нее, а японское правительство приняло на себя обязательство, предусматривающее, что и сама Япония будет всё в большей мере принимать на себя ответственность за собственную оборону ${ }^{32}$, т.е. постепенно, но неуклонно следовать по пути милитаризма.

Таким образом, США и их союзники после окончания Второй мировой войны стали открыто саботировать юридическую договоренность с Советским Союзом мирного урегулирования с Японией, стали на путь сепаратистского сговора с японской реакцией, игнорируя ранее подписанные международные соглашения. Однако, несмотря на имевшиеся сложности в отношениях с Японией, связанных опять-таки с территориальными притязаниями соседа, по истечению времени установились определенные экономические связи, приведшие в последующем и к политическим отношениям. Так, 11 сентября 1956 года тогдашний японский премьер Хатояма обратился с письмом к Председателю Совета Министров СССР, в котором изложил свое видение перспектив для возобновления дипломатических отношений. В письме, в частности, содержалось несколько пунктов: провозглашение окончания состояния войны; обмен посольствами; возвращение на родину военнопленных; вступление в силу ранее подписанной рыболовной конвенции; поддержка Советским Союзом обращения Японии о приеме ее в ООН..3 Советское правительство положительно отнеслось к японской инициативе и выразило готовность на приемлемой основе начать переговоры о нормализации советско-японских отношений.

Переговоры состоялись в Москве с 13 по 19 октября 1956 года и закончились подписанием «Совместной декларации Союза Советских Социалистических Республик и Японии». Статья 1 Совместной декларации провозглашала, что состояние войны между Советским Союзом и Японией «прекращается со дня вступления в силу настоящей Декларации», и между обеими странами «восстанавливают-

32 Сборник документов и материалов по Японии. 19511954 гг. СССР. - М., . Изд-во МИД 1954.С.129.

33 Кутаков Л.Н. История советско-японских дипломатических отношений. - М., 1962. С. 500. 


\section{История международных отношений / History of international relations}

ся мир и добрососедские дружеские отношения» ${ }^{34}$. Восстанавливались также дипломатические и консульские отношения и предусматривался обмен дипломатическими представителями в ранге послов.

В соответствии сост. 9 обе страны согласились, что после восстановления нарушенных дипломатических отношений они намерены продолжить переговоры о заключении мирного договора. Причем оговаривалось, что после вступления в силу этого договора, Советский Союз пойдет на уступку Японии островов Хабомай и Сикотан. По нашему мнению, такая уступка может иметь место при всех других составляющих, если Япония выполнит ранее принятые международные соглашения в период и по окончании Второй мировой войны, в том числе и относительно американских военных баз на своей территории.
Совместная Декларация вступила в силу 12 декабря 1956 года после обмена ратификационными грамотами.

Впрочем, с Германией у нас тоже нет мирного договора, но это не мешало и не мешает развивать советско-германское многостороннее взаимовыгодное сотрудничество. Собственно, на наш взгляд, «мирный договор» нужен в первую очередь не Российской Федерации, а японской стороне. Японии он необходим исключительно на японских условиях, чтобы под «занавесом» этого «договора» добиться своих территориальных притязаний. Нам представляется, что через минувшее десятилетие после окончания войны российскому и японскому народам не так уж и важен «мирный договор», а объективно целесообразен договор о добрососедстве и сотрудничестве.

\section{Библиография}

1. Российская газета. 2013. 27 декабря.

2. Анисимов Л.Н. Международное право о несостоятельности территориальных притязаний Японии к России как продолжателю СССР//Дипломатическая служба. 2014. №1. С. 36-44.

3. Клименко Б.М. Государственная территория. Вопросы теории и практики международного права. М., 1974. С. 38-86;

4. Клименко Б.М., Ушаков Н.А. Нерушимость границ - условия международного мира. - М., 1975. С .20-22, $32-45,120-135$.

5. Зимонин В.П. Последняя точка во Второй мировой войне. - М., 2005. С. 16-55).

6. Российская газета. 2010. 31 августа.

7. Российская газета. 2013. 19 ноября.

8. Николаев А.Н. Токио: суд народов. - М.,1990.

9. Гольденберг Д.И. Внешняя политика Японии в 1941 - 1945 гг. - М., 1962. С.74-75).

10. К Кузнец Ю.Л. От Пёрл-Харбора до Потсдама. - М., 1970. С. 135.

11. Внешняя политика Советского Союза в период Отечественной войны. - М., 1947. С. 110-112.

12. Ялтинское соглашение трех великих держав по вопросам Дальнего Востока// Внешняя политика в период Отечественной войны. Т.3. - М., 1947. С. 111-112.

13. W.Churchill. The Second War. Vol. VI. P. 389.

14. Потсдамская декларация// Сборник действующих договоров, соглашений и конвенций, заключенных СССР с иностранными государствами. Вып. ХІ. - М., 1955. С.104-106.

15. Внешняя политика Советского Союза. 1945. - М., 1949. С. 155-160.

16. Сборник решений Дальневосточной Комиссии (февраль 1946 - июль 1948 гг). - М., МИД СССР, 1948. C. 1215.

17. Сборник нот и заявлений правительств СССР, США, Китая, Англии и других стран по вопросам мирного урегулирования для Японии. Июль 1947- июль 1951 гг.. - М., МИД СССР 1951.

18. Сборник документов и материалов по Японии. 1951-1954. - М., 1954.

19. Заявление А.А. Громыко на пресс-конференции в Сан-Франциско 8 сентября 1951 года // Правда. 1951. 10 сентября.

20. Русские Курилы: История и современность: Сборник документов по формированию русско-японской и советско-японской границы. - М., 1955.

21. Кутаков Л.Н. История советско-японских дипломатических отношений. - М., 1962. С. 500.

34 Правда. 1956. 20 октября. 


\section{Международные отношения / International Relations}

22. Правда. 1956. 20 октября.

23. Гушер А.И. Вызовы и угрозы безопасности России // NB: Международные отношения. - 2014. - 1. C. 64-75. DOI: 10.7256/2306-4226.2014.1.10748. URL: http://www.e-notabene.ru/wi/article_10748.html

24. Манойло А.В. Геополитическая картина современного мира // Национальная безопасность / nota bene. - 2013. - 5. - C. 149-155. DOI: 10.7256/2073-8560.2013.5.9394.

25. Манойло А.В. Стратегии «управляемого хаоса» в условиях хаотизации международных отношений: миф или реальность? // NB: Международные отношения. - 2014. - 1. - С. 1-3. DOI: 10.7256/23064226.2014.1.10750. URL: http://www.e-notabene.ru/wi/article_10750.html

26. Манойло А.В. Ценностные основы управления межцивилизационными конфликтами: российская модель // NB: Международные отношения. - 2012. - 1. - C. 32-43. URL: http://www.e-notabene.ru/wi/ article_279.html

\section{References}

1. Rossiiskaya gazeta. 2013. 27 dekabrya.

2. Anisimov L.N. Mezhdunarodnoe pravo o nesostoyatel'nosti territorial'nykh prityazanii Yaponii k Rossii kak prodolzhatelyu SSSR//Diplomaticheskaya sluzhba. 2014. №1. S.36 - 44.

3. Klimenko B.M. Gosudarstvennaya territoriya. Voprosy teorii i praktiki mezhdunarodnogo prava. - M., 1974. S. 38-86.

4. Klimenko B.M., Ushakov N.A. Nerushimost' granits - usloviya mezhdunarodnogo mira. - M., 1975. S. 20-22, $32-45,120-135$.

5. Zimonin V.P. Poslednyaya tochka vo Vtoroi mirovoi voine. - M., 2005. S. 16-55).

6. Rossiiskaya gazeta. 2010. 31 avgusta.

7. Rossiiskaya gazeta. 2013. 19 noyabrya.

8. Nikolaev A.N. Tokio: sud narodov. - M.,1990.

9. Gol'denberg D.I. Vneshnyaya politika Yaponii v 1941 - 1945 gg. - M., 1962. S. 74-75).

10. Kuznets Yu.L. Ot Perl-Kharbora do Potsdama. - M., 1970. S.135.

11. Vneshnyaya politika Sovetskogo Soyuza v period Otechestvennoi voiny. - M., 1947. S. 110-112;

12. Yaltinskoe soglashenie trekh velikikh derzhav po voprosam Dal'nego Vostoka// Vneshnyaya politika v period Otechestvennoi voiny. T.3. - M., 1947. S. 111-112.

13. W.Churchill. The Second War. Vol. VI. R. 389.

14. Potsdamskaya deklaratsiya// Sbornik deistvuyushchikh dogovorov, soglashenii i konventsii, zaklyuchennykh SSSR s inostrannymi gosudarstvami. Vyp. XI. - M., 1955. S. 104-106.

15. Vneshnyaya politika Sovetskogo Soyuza. 1945. - M., 1949. S. 155-160.

16. Sbornik reshenii Dal'nevostochnoi Komissii (fevral' 1946 - iyul' 1948 gg).. - M., MID SSSR, 1948. S. 1215.

17. Sbornik not i zayavlenii pravitel'stv SSSR, SShA, Kitaya, Anglii i drugikh stran po voprosam mirnogo uregulirovaniya dlya Yaponii. Iyul' 1947- iyul' 1951 gg.. - M., MID SSSR 1951.

18. Sbornik dokumentov i materialov po Yaponii. 1951-1954. - M., 1954.

19. Zayavlenie A.A. Gromyko na press-konferentsii v San-Frantsisko 8 sentyabrya 1951 goda // Pravda. 1951. 10 sentyabrya.

20. Russkie Kurily: Istoriya i sovremennost': Sbornik dokumentov po formirovaniyu russko-yaponskoi i sovetskoyaponskoi granitsy. - M., 1955.

21. Kutakov L.N. Istoriya sovetsko-yaponskikh diplomaticheskikh otnoshenii. - M., 1962. S. 500.

22. Pravda. 1956. 20 oktyabrya.

23. Gusher A.I. Vyzovy i ugrozy bezopasnosti Rossii // NB: Mezhdunarodnye otnosheniya. - 2014. - 1. - S. 64-75. DOI: 10.7256/2306-4226.2014.1.10748. URL: http://www.e-notabene.ru/wi/article_10748.html

24. Manoilo A.V. Geopoliticheskaya kartina sovremennogo mira // Natsional'naya bezopasnost' / nota bene. 2013. - 5. - S. 149-155. DOI: 10.7256/2073-8560.2013.5.9394.

25. Manoilo A.V. Strategii «upravlyaemogo khaosa»v usloviyakh khaotizatsii mezhdunarodnykh otnoshenii: mif ili real'nost'? // NB: Mezhdunarodnye otnosheniya. -2014. -1.-S. 1-3. DOI: 10.7256/2306-4226.2014.1.10750. URL: http://www.e-notabene.ru/wi/article_10750.html

26. Manoilo A.V. Tsennostnye osnovy upravleniya mezhtsivilizatsionnymi konfliktami: rossiiskaya model' // NB: Mezhdunarodnye otnosheniya. - 2012. - 1. - S. 32-43. URL: http://www.e-notabene.ru/wi/article_279.html 